Studia Anglica Posnaniensia 49/4, 2014

doi: 10.1515/stap-2015-0012

\title{
THE TRANSFORMATIONS OF THE NOVELISTIC CANON: THE COMPARISON OF DANIEL DEFOE'S AND PENELOPE AUBIN'S DEDICATION TO TRUTH AND VIRTUE
}

\author{
JOANNA MACIULEWICZ
}

Faculty of English, Adam Mickiewicz University in Poznań

\begin{abstract}
The aim of the article is to discuss the evolution of the concept of the literary canon in the context of eighteenth-century fiction. The concept of the literary canon has been traditionally associated with timeless, universal values which transcend the ideological conditions of the period in which texts are created. In present criticism, which is shaped by cultural studies, the association of a canon with universality has been challenged. A canon has been recognised by cultural critics as an instrument of an ideological power struggle which presents the values of dominant social groups as universal. The analysis of novels written by Penelope Aubin and Daniel Defoe at the beginning of the eighteenth century demonstrates that the study of literature only from an ideological viewpoint does not account for the workings of the literary canon. Both Aubin and Defoe employ the same formula of fiction, adventure story with a moral commentary, but while Defoe's fiction has survived in literary histories, Aubin's stories, after their initial success, fell into oblivion and have been rediscovered only recently by feminist critics. The varying fates of Aubin's and Defoe's fiction point to the insufficiency of the definition of canon which binds literary value too strongly with ideology.
\end{abstract}

Keywords: canon, eighteenth-century fiction, ideology, cultural studies, Aubin

One of the oldest challenges to literary studies is the explanation of the principles of canon formation which would be satisfactory to most critics and readers. Nowadays the dominant view is that they will most probably never be found, if only because there is no agreement about what the canon is. The ideal (or idealistic) definition would be that a canon is a collection of literary works characterised by inherent, universal values independent of the petty interests of current politics or moral ideology. It seems that the eighteenth-century understanding of the term 
partakes of the idealism in the way literature, or art at large, is perceived. David Hume in an essay published in 1757 argues that despite the proverbial conviction about the lack of the standard of taste even within groups of uniform cultural background, "there is certainly a species of common sense that opposes it, at least serves to modify and restrain it" (Hume 2001 [1757]: 488). There are works which are universally admired and once they are freed from the pressures of their own contemporaneity, their value becomes fully evident. "Authority or prejudice may give a temporary vogue to a bad poet or orator", he says, "but his reputation will never be durable or general. When his compositions are examined by posterity or by foreigners, the enchantment is dissipated, and his faults appear in true colours" (Hume 2001 [1757]: 489-90). Dr Johnson likewise believes that time is "the test of literary merit" since it is impossible to see the true value of literature within its original context of creation and reception. "Whatever advantages he [the author] might once derive from personal allusions, local customs, or temporary opinions", when the "effects of favour and competition are at an end; the tradition of enmities has perished; his works support no opinion with arguments, nor supply any faction with invectives; they can neither indulge vanity nor gratify malignity but are read without any other reason than the desire of pleasure, and are therefore praised only as pleasure is obtained". It is only in the texts that "have passed through variations of taste and changes of manners" that we may look for some intrinsic artistic value (Johnson 2000 [1765]: 420).

In contemporary criticism the concept of a canon is no longer so closely associated with inherent literary merit which transcends ideological contingencies. On the contrary, it is more commonly believed that the merit is dependent on prevalent ideologies and extra literary conditions. The view at its extreme was expressed by Terry Eagleton in his introduction to Literary theory. An introduction (1983) wherein he argued that that "the so-called 'literary canon' ... has to be recognised as a construct", that "there is no such thing as a literary work or tradition which is valuable in itself" and that value is "a transitive term", which "means whatever is valued by certain people in specific situations, according to particular criteria and in the light of given purposes" (Eagleton 1983: 11). This view, however, is fiercely opposed by Harold Bloom, the author of a study entitled The Western Canon (1994), who is a vehement advocate of the traditional conceptualisation of the canon. Bloom insists that it is a mistake to perceive the survival of particular literary texts only as an outcome of ideological forces, to believe that "to make a canon is an ideological act in itself" (Bloom 1994: 21). For him the canon is to be seen as "the relation of an individual reader and writer to what has been preserved out of what has been written", or, in other words, as "the literary art of Memory" (Bloom 1994: 17).

The debate between the two concepts of canon formation is particularly interesting to observe in the context of eighteenth-century fiction. It is commonly 
believed that the formation of genres is governed by the same logic as the formation of the canon: genres crystallise as a result of the interplay of various cultural, philosophical, and economic forces. Texts which cohere with the epistemology and ideology of the period contribute to the consolidation of a genre. This approach, however, seems to overemphasise the extra literary context at the expense of the aesthetic, resonance at the expense of wonder, to use Stephen Greenblatt's (1990) terms. Cultural historians of literature go to great lengths to demonstrate the errors of the aesthetic approach to literary evolution, arguing that the aesthetic is nothing but disguised ideology, which can be shown by the recovery of the original context of the creation and reception of literary texts. And yet the passage of time distils texts capable to evoke wonder at their uniqueness from those which can merely produce resonance, that is "to evoke ... the complex, dynamic cultural forces" from which they have "emerged" and for which they "may be taken ... to stand" (Greenblatt 1990: 170), which may be evidence of literature's power to overcome ideologies.

The analysis of Penelope Aubin's narratives in comparison to those by Daniel Defoe may reveal that the ideological explanation of the genre and canon formation fails to do full justice to the complexity of the workings of cultural memory. Both authors employed similar models of fiction and yet it is Daniel Defoe who has survived the test of time whereas Penelope Aubin disappeared from literary histories for a long time. William Warner, the proponent of the cultural explanation of the development of literature, argues that Defoe's narratives have entered the literary canon since they were skilful adaptations of the highly popular formula of the adventure story and amorous novel to the moral ideology of a target reading audience. In his "double-voiced memoir narratives" Defoe could reconcile the demands of a pleasure-driven market with the need for moral content, the immediacy of the first-person account of a vicious life with the distance of retrospective repentance (Warner 1998: 151). In Moll Flanders, to give one instance of how the narrative is structured, the putative editor explains that "to give the history of a wicked life repented of, necessarily requires that the wicked part should be made as wicked as the real history of it will bear, to illustrate and give a beauty to the penitent part, which is certainly the best and brightest, if related with equal spirit and life" (Moll Flanders, 2).

If this were sufficient to gain a position in the history of literature, Penelope Aubin should have secured for herself a permanent place. Her design is no different from that of Defoe. The indebtedness of Aubin's plots to Defoe's narratives has been widely recognised. William H. McBurney calls her "the boldest and most productive imitator of Defoe's works" (McBurney 1957: 246) and enumerates various kinds of her borrowings: starting with specific elements of the plot and the themes like "disobedience of parental will" or "necessity as a cause of sin", finishing with "general resemblances of style and structure" such 
as episodic plots or moralising digressions. Her aim is, as she herself says in the preface to The Strange Adventures of the Count de Vinevil and his Family (1721), "to reclaim our giddy youth", "try to win them to virtue, by methods where delight and instruction may go together". The methods include depicting "men [who] behave like Christians and women [who] are really virtuous, and such as we ought to imitate" (Count Vinevil, 114). Just like Defoe, as Chris Mounsey notes, she knows how to "mix adventure with a pious project" (Mounsey 2003: 59). In this way she manifests particular sensitivity both to the demands of the market and the moral ideology of her times.

Aubin's protestations of her dedication to the cause of virtue have proved to be very convincing to numerous critics until very recently. The author of the preface to the 1739 collective edition of her tales, who, as some critics suspect, might have been Richardson himself, extols Aubin's “one uniform end which was the principal scope of her writings; the mending of the hearts of her readers, the encouragement of religion and virtue and the discountenancing of impiety and vice". McBurney in 1957 speculates that Aubin might have inspired Samuel Richardson himself, probably the most dedicated propagator of virtue among eighteenth-century novelists. Jane Spencer in 1986 echoes the belief saying that "[c]ertainly Penelope Aubin's determined efforts to moralize fiction provided Richardson with a precedent for his 'new species of writing', intended 'to promote the cause of religion and virtue" and declares that "morality for her was the proper aim of fiction" while literature was but a means of preaching, which she actually took up at the end of her life (Spencer 1986: 86, 87, 88). It is only recently that Aubin's claims to morality have been put in doubt. Chris Mounsey bluntly describes her work as a thinly disguised "pornographic fantasy" abundant in "explicit and sexually charged [erotic scenes]" and "regular bonecrunching and cartoon violence" (Mounsey 2003: 59, 60, 59). And yet the two strains in the texture of her fiction are still clearly seen, whether we believe that voyeuristic pleasure derived from reading about vicious lives was a pretext to offer moral messages, as Aubin maintains, or moralising was just a means of smuggling lasciviousness and violence into the plots.

In combining pleasure with piety Penelope Aubin turns out to be as skilful a player on the literary market as Daniel Defoe, practising this formula of fiction which would be legitimized by literary historians. And yet, despite some initial success, her fiction fell into oblivion for a long time only to be discovered by scholars working on women's writings. Even now, after her name has been mapped on literary history, Aubin is described as a merely popular writer and contrasted with "the great mid-century novelists [who] relegated her novels to obscurity" (McBurney 1957: 267). Defoe, Richardson, Aubin all protested the propagation of virtue with the aid of pleasurable fiction, and out of the three only Aubin's works failed to persevere in literary histories, from which she was 
obliterated just as Haywood and Manley from whom she was trying to distance herself. The causes for her disappearance from the canon cannot be seen in her nonconformity with the expectations of her readers or moralists.

The reason for Aubin's failure may be the excessive conformity to the ideology of her period manifested in the way she constructed her moral instruction. The concept of Christian virtue presented to the reader is extremely crude and is virtually reduced to an intricate codex of rules of how to protect chastity. "Permit not a vile infidel to dishonour you, resist to death, and let me not be so completely cursed to hear you live and are debauched", Ardelisa, the protagonist of Count Vinevil, hears directly after her wedding from her new husband. "Forgive me, Ardelisa, I know your virtue's strong, though you are weak, but force does oft prevail" (Count Vinevil, 121). Ardelisa's husband does not specify to whose death she should resist but it seems that there can be only one correct interpretation since suicide is not allowed by Christian moral code. Ardelisa, thus, when threatened with the loss of her virtue by a lustful Turk hesitates but a while about how she should protect her virtue. "Shall this bold hand destroy the villain when he enters? Sure it can be no sin to save my virtue with his blood" (Count Vinevil, 132). An alternative method of the preservation of a heroine's virtue, mercilessly ridiculed by Aparna Gollapudi, consists in "a rather atypical strategy of resisting her ravisher" (Gollapudi 2005: 669). The protagonist of Noble Slaves tears her eyes out and throws them at the assaulter. "My Eyes are sacrificed to virtue ... I would have done more, had Christianity permitted, and would have died, but I have cheaply bought my repose with the loss of one sense" (Noble Slaves, 69). The defence of virtue did not allow suicide but justified murder and self-mutilation.

We find out, however, that the principles are not the same for all women. In one of subplots of Count Vinevil Aubin presents the story of a beautiful Venetian girl, enslaved by another lustful Turk. When she meets Ardelisa and becomes familiar with her unfailing virtue, she reconsiders her own situation.

Father, till I saw Ardelisa I found my conscience undisturbed, I submitted to the
fatal necessity of my circumstances; and Christianity forbidding me to finish life
by my own hand, I thought I had done all that was required. But that noble lady's
heroic conduct has convinced me I did not do what I ought. She never would have
permitted a lustful Turk to possess her, but by his death would have preserved her,
or resisting to death not have survived it.

(Count Vinevil, 139)

She is however rapidly consoled learning that the code of conduct for virgins is different from that for married women. 
The priest answered, 'Madam, you are deceived. In Ardelisa, who was married to another, it would be a horrid crime to suffer another man for to possess her, but as you were single, a virgin, and made his by the chance of war, it was no sin in you to yield to him, and it would have been wilful murder to kill him, or but conspire his death.

(Count Vinevil, 139; my emphasis)

To summarise, murder is a sin if it is committed by a virgin in defence of her virtue, but it is not if it is perpetrated by a married woman. A virgin, threatened with a loss of virtue, is advised to mutilate herself or yield to the force, since her surrender is no sin provided she keeps faith to the bed of the man who first ravished her. A married woman should keep faith to her husband at all costs since it would be "a horrid crime to suffer another man for to possess her". Female virtue seems immensely reductive if it is viewed merely as the protection of a man's exclusive right to the body of a woman.

Aubin's representation of morality is not only reductive but also fairly mechanical. As the author of the preface to the collective edition spells out, in a truly moral narrative "when a guilty Character is introduced, it should in the Conclusion appear to be signally punished or distressed, that others may be deterred from the Pursuits of those Follies, or Mistakes, which have been the Occasion of its Misfortunes" and "That Virtue or Innocence, on the contrary, be not finally permitted to suffer; but that a Prospect at least should be opened, either here or hereafter, for its Reward, in order to encourage every one who reads it to Imitation" (Aubin, Preface). This insistence on poetic justice as well as the trust in the workings of divine Providence is an excellent instrument for the instilment of socially desirable values, which remains in agreement with the general ideology of the period. What is more, the poetic justice, as Hernadez has convincingly demonstrated in his article on providence in Clarissa, is a perfect fusion of the ideology of the market and religion. "Poetic justice is the literary supplement to the normalizing processes necessary to make markets work - a process of exchange that marries moral and commercial conduct in order to efficiently derive calculable, profitable results. "Good" actions are the narratological commodity - form of labour, advanced against future ages from on high" (Hernandez 2010: 610). Aubin's narratives are thus a perfect enactment of the cultural forces of her times.

The literary merit, however, is not the consequence of the work's coherence with the cultural forces of the external world. Samuel Johnson in his preface to Shakespeare's plays argues that the writer's merit lies in the fact that "he holds up to his readers a faithful mirror of manners and of life". But "[h]is characters are not modified by the customs of particular places, unpractised by the rest of the world; by the peculiarities of studies or professions, which can operate but upon small numbers; or by the accidents of transient fashions or temporary 
opinions: they are the genuine progeny of common humanity, such as the world will always supply, and observation will always find" (Johnson 2000: 421). Harold Bloom, sometimes compared to Dr Johnson, claims that the greatness of literature is not social in nature. It is "an individual rather than a societal concern", Bloom (1994: 16) insists. What the story of the fortunes of Aubin's texts teaches us is that the cultural approach to the subject of a canon and genre formation misses the explanation of what is essential in literature. They largely contribute to our understanding of the relations of what Pierre Bourdieu calls the field of cultural production with other fields but it is not able to pinpoint what Defoe shows about human nature which Aubin failed to illustrate. Aubin's stories are clearly designed to reinforce social norms whereas Defoe, while protesting his stories' service to the cause of morality, captures the universal tension between society and an individual who recognises that a publicly preached virtue may have little to do with genuine benevolence and be but an instrument of solidifying an ideology, which can work to the detriment of an individual. Mario Vargas Llosa in his Nobel Prize lecture associates literature with the alertness to the snares of ideology. "We would be worse than we are without the good books we have read, more conformist, not as restless, more submissive, and the critical spirit, the engine of progress, would not even exist", he explains.

\begin{abstract}
Without fictions we would be less aware of the importance of freedom for life to be liveable, the hell it turns into when it is trampled underfoot by a tyrant, an ideology, or a religion. Let those who doubt that literature not only submerges us in the dream of beauty and happiness but alerts us to every kind of oppression, ask themselves why all regimes determined to control the behavior of citizens from cradle to grave fear it so much they establish systems of censorship to repress it and keep so wary an eye on independent writers.
\end{abstract}

(Vargas Llosa, 2010)

In our attempts to describe the process of the shaping of the canon, and of the genres, it seems most essential to comprehend that the most valuable texts are the outcome of contradictory forces operating simultaneously, ideological and counter-ideological, and if we manage to describe the dialectic we will be able to explain the nature of universal literary value more precisely.

\title{
REFERENCES
}

Aubin, Penelope. 1996. The strange adventures of the count de Vinevil and his family. In Backscheider, Paula R. \& John J. Richetti (eds.), Popular fiction by women 1660-1730. An anthology, 113-151. Oxford: Oxford University Press. 
Aubin, Penelope. 1778. Noble slaves. In A collection of novels selected and revised by Mrs Griffith. Vol. III. http://archive.org/stream/collectionofnove03grifiala\#page/n3/mode/2up (accessed 15 July 2012).

Aubin, Penelope. Preface to collected novels. http://www.munseys.com/diskone/nobleslavedex. htm (accessed 15 July 2012).

Bloom, Harold. 1994. The Western canon. The books and schools of the ages. New York: Riverhead Books.

Defoe, Daniel. 1994. Moll Flanders. London: Penguin Books.

Eagleton, Terry. 1983. Literary theory. An introduction. Minneapolis: University of Minnesota Press.

Gollapudi, Arna. 2005. Virtuous voyages in Penelope Aubin's fiction. Studies in English Literature, 1500-1900 (Restoration and Eighteenth Century) 45(3). 669-690.

Greenblatt, Stephen J. 1990. Learning to curse. Essays in Early Modern culture. New YorkLondon: Routledge.

Hernandez, Alex Eric. 2010. Tragedy and economics of providence in Richardson's Clarissa, Eighteenth-Century Fiction 22. 599-630.

Hume, David. 2001 [1757]. Of the standard of taste. In Leitch, Vincent B. (ed.), The Norton anthology of theory and criticism, 486-499. New York \& London: WW Norton \& Company.

Johnson Samuel. 2000 [1765]. The plays of William Shakespeare. Preface. In Greene, Donald (ed.), Samuel Johnson. The major works, 419-456. Oxford: Oxford University Press.

Leitch, Vincent B. (ed.). 2001. The Norton anthology of theory and criticism. New York \& London: WW Norton \& Company.

McBurney, William H. 1957. Mrs Penelope Aubin and the early eighteenth-century English novel, Huntington Library Quarterly 20(3). 245-267.

Mounsey, Chris. 2003. ... bring her Naked from her Bed, that I may ravish her before the Dotard's face, and then send his Soul to Hell': Penelope Aubin, impious pietist, humourist or purveyor of juvenile fantasy? British Journal for Eighteenth-Century Studies 26. 55-75.

Spencer, Jane. 1986. The rise of the woman novelist. From Aphra Behn to Jane Austen. OxfordNew York: Basil Blackwell.

Vargas Llosa, Mario. 2010. Nobel Prize Lecture. http://www.nobelprize.org/nobel_prizes/ literature/laureates/2010/vargas_llosa-lecture_en.html (accessed 1 April 2012).

Warner, William B. 1998. Licensing entertainment. The elevation of novel reading in Britain, 1684-1750. Berkeley, Los Angeles \& London: University of California Press. 